\title{
Phytosphingosine-1-phosphate stimulates chemotactic migration of L2071 mouse fibroblasts via pertussis toxin-sensitive G-proteins
}

\author{
Mi-Kyoung Kim ${ }^{1,2}$, Kyoung Sun Park', \\ Hyuck Lee ${ }^{3}$, Young Dae $\mathrm{Kim}^{3}$, \\ Jeanho Yun ${ }^{1,2}$ and Yoe-Sik Bae ${ }^{1,2,4}$ \\ ${ }^{1}$ Medical Research Center for Cancer Molecular Therapy \\ ${ }^{2}$ Department of Biochemistry \\ ${ }^{3}$ Department of Internal Medicine \\ College of Medicine, Dong-A University \\ Busan 602-714, Korea \\ ${ }^{4}$ Corresponding author: Tel, 82-51-240-2889; \\ Fax, 82-51-241-6940; E-mail, yoesik@donga.ac.kr
}

Accepted 9 February 2007

Abbreviations: BAPTAIAM, 1,2-bis (Aminophenoxy) ethane-N,N,N',N'tetraacetoxymethyl ester; $\left[\mathrm{Ca}^{2+}\right]$, intracellular calcium concentration; GPCRs, G-protein coupled receptors; IP3, inositol-1,4,5-trisphosphate; LPA, lysophosphatidic acid; PD98059, 2'-amino-3'-methoxyflavone; PhS1P, phytosphingosine-1-phosphate; PI3K, phosphatidylinositol-3-kinase; PTX, pertussis toxin; LY294002, 2-(4-Morpholinyl)-8-phenyl-4H-1-benzopyran-4-one; S1P, sphingosine-1phosphate; SB203580, 4-(4-fluorophenyl)-2-(4-methylsulfinylphenyl)5-(4-pyridyl)1H-imidazole; U-73122, 1-[6-((17ß-3-methoxyestra-1,3, 5(10)-trien-17-yl)amino) hexyl]-1H-pyrrole-2,5-dione; U-73343, 1-[6((17 $\beta$-3-methoxyestra-1,3,5(10)-trien-17-yl)amino)hexyl]-2,5-pyrrolidinedione

\footnotetext{
Abstract

Phytosphingosine-1-phosphate (PhS1P) was found to stimulate an intracellular calcium increase via phospholipase $C$ but not pertussis toxin (PTX)sensitive G-proteins in L2071 mouse fibroblasts. PhS1P also activated ERK and p38 kinase, and these activations by PhS1P were inhibited by PTX. Moreover, PhS1P stimulated the chemotactic migra tion of L2071 cells via PTX-sensitive $G_{i}$ protein(s). In addition, the PhS1P-induced chemotactic migration of L2071 cells was also dramatically inhibited by LY294002 and SB203580 (inhibitors of phosphoinositide 3-kinase and p38 kinase, respectively). L2071 cells are known to express four S1P receptors, i.e., $S 1 P_{1}, S_{1} P_{2}, S 1 P_{3}$, and $S 1 P_{4}$, and pretreatment with an $S_{1} P_{1}$ and $S 1 P_{3}$ antagonist (VPC 23019) did not affect on PhS1P-induced chemotaxis. This study
}

demonstrates that PhS1P stimulates at least two different signaling cascades, one is a PTX-insensitive but phospholipase $C$ dependent intracellular calcium increase, and the other is a PTX-sensitive chemotactic migration mediated by phosphoinositide 3-kinase and p38 kinase.

Keywords: calcium signaling; chemotaxis; fibroblasts; GTP-binding proteins; pertussis toxin; phytosphingosine-1-phosphate

\section{Introduction}

Many reports have demonstrated the involvement of lipid factors in cellular responses. In particular, sphingosine-1-phosphate (S1P) and lysophosphatidic acid (LPA) are important lipid mediators, which modulate a wide range of physiological activities (van Corven et al., 1989; English et al., 1999; Wang et al., 1999; Fishman et al., 2001; Cummings et al., 2002; Idzko et al., 2002; Kim et al., 2004). For example, S1P has been reported to induce chemotactic migration and angiogenesis in human umbilical vein endothelial cells (English et al., 1999; Wang et al., 1999), and to induce cellular chemotaxis and modulate cytokine release in mature human dendritic cells during Th2 immune responses (Idzko et al., 2002) and in human bronchial epithelial cells (Cummings et al., 2002). Moreover, LPA has been reported to regulate the cellular migration of ovarian cancer cells (Fishman et al., 2001), and to regulate the proliferation of several cell types, including fibroblasts and amniotic cells (van Corven et al., 1989; Kim et al., 2004). Although several previous reports have demonstrated the pivotal roles of S1P and LPA in the modulation of several biological responses via their specific receptors, the role of other lipid mediators should clearly be considered. Phytosphingosine-1-phosphate (PhS1P) can be generated by the phosphorylation of phytosphingosine, and is one of the most widely distributed natural sphingoid bases which is found abundantly in fungi and plants, but which is also found in animals including man (Shurer et al., 1991; Dickson, 1998). Moreover, PhS1P is structurally similar to S1P, i.e., PhS1P has a hydroxyl group at $\mathrm{C}-4$ of the sphingoid long-chain base, whereas S1P has a trans-double bond be- 
tween C-4 and C-5. Although PhS1P is present in animals as a minor component of cell membranes, the physiological role of PhS1P in the modulation of cellular activities has not been previously studied.

In terms of S1P cell surface receptors, a family of G-protein coupled receptors (GPCRs) has been shown to contain specific S1P sites (An et al., 1997, 2000; Okamoto et al., 1998; Yamazaki et al., 2000). This family includes $\mathrm{S}_{1} \mathrm{P}_{1}, \mathrm{~S}_{1} \mathrm{P}_{2}, \mathrm{~S}_{1} \mathrm{P}_{3}$, and $\mathrm{S}_{1} \mathrm{P}_{4}(\mathrm{An}$ et al., 1997, 2000; Okamoto et al., 1998; Yamazaki et al., 2000), and previous reports have demonstrated that PhS1P also acts on cell surface bound GPCRs, $\mathrm{S}_{1 \mathrm{P}_{4}}$ and $\mathrm{S}_{1} \mathrm{P}_{1}$ (Candelore et al., 2002; Inagaki et al., 2005). Moreover, even though PhS1P has been known to bind $\mathrm{S}_{1} \mathrm{P}_{4}$ or $\mathrm{S}_{1} \mathrm{P}_{1}$, its effect on cellular functioning has not been previously investigated. In this study, we investigated PhS1P-induced cell migration and the signaling pathways involved in L2071 mouse fibroblasts. We found that two separate signaling pathways are involved together with pertussis toxin (PTX)-sensitive trimeric $\mathrm{G}$ proteins.

\section{Materials and Methods}

\section{Reagents and cell culture}

PhS1P, S1P, and VPC 23019 were purchased from Avanti Polar Lipids, Inc. (Alabaster, AL). The reverse transcription-PCR kit was purchased from Invitrogen Corporation (Carlsbad, CA), and FBS from Hyclone (Logan, UT). Enhanced chemiluminescence reagents were from Amersham Biosciences (Piscataway, NJ), and phospho-ERK1/2, phospho-p38 kinase, and ERK2 antibodies from New England Biolabs (Beverly, MA). 2-(4-Morpholinyl)-8-phenyl-4H-1-benzopyran-4one (LY294002), 1-[6-((17ß-3-Methoxyestra-1,3,5(10)trien-17-yl)amino)hexyl]-1H-pyrrole-2,5-dione (U-73122), 1-[6-((17ß-3-Methoxyestra-1,3, 5(10)-trien-17yl)amino) hexyl]-2,5-pyrrolidinedione (U-73343), 1,2-bis (Aminophenoxy) ethane-N,N,N', N'-tetraacetoxymethyl ester (BAPTA/AM), 2'-Amino-3'-methoxyflavone (PD98059), and 4-(4-Fluorophenyl)-2-(4-methylsulfinylphenyl)-5-(4-pyridyl) 1H-imidazole (SB203580) were obtained from Calbiochem (San Diego, CA) and were dissolved in DMSO before being added to cell culture. The final concentrations of DMSO in culture were $0.1 \%$ or less. L2071 mouse fibroblasts were purchased from American Type Culture Collection (Manassas, VA) and cultured in RPMI 1640 medium with $10 \%$ FBS, $1 \%$ sodium bicarbonate buffer.

\section{$\mathrm{Ca}^{2+}$ measurement}

Intracellular calcium concentration $\left(\left[\mathrm{Ca}^{2+}\right]_{i}\right)$ was determined by Grynkiewicz's method using fura-2/ AM (Grynkiewicz et al., 1985). Briefly, prepared cells were incubated with $3 \mu \mathrm{M}$ fura-2/AM at $37^{\circ} \mathrm{C}$ for $50 \mathrm{~min}$ in fresh serum free RPMI 1640 medium with continuous stirring. $2 \times 10^{6}$ cells were aliquoted for each assay into Locke's solution (154 mM NaCl, $5.6 \mathrm{mM} \mathrm{KCl}, 1.2 \mathrm{mM} \mathrm{MgCl}_{2}, 5$ $\mathrm{mM}$ HEPES, $\mathrm{pH} 7.3,10 \mathrm{mM}$ glucose, $2.2 \mathrm{mM}$ $\mathrm{CaCl}_{2}$, and $0.2 \mathrm{mM}$ EGTA). Fluorescence was measured at $500 \mathrm{~nm}$ at excitation wavelengths of $340 \mathrm{~nm}$ and $380 \mathrm{~nm}$.

\section{Stimulation of cells with PhS1P for Western blot analysis}

Cultured cells $\left(2 \times 10^{6}\right)$ were stimulated with the indicated concentrations of PhS1P for the predetermined lengths of time. After stimulation, the cells were washed with serum free RPMI 1640 medium and lysed in lysis buffer (20 mM Hepes, pH 7.2, 10\% glycerol, $150 \mathrm{mM} \mathrm{NaCl}, 1 \%$ Triton X-100, $50 \mathrm{mM}$ $\mathrm{NaF}, 1 \mathrm{mM} \mathrm{Na} \mathrm{VO}_{4}, 10 \mu \mathrm{g} / \mathrm{ml}$ leupeptin, $10 \mu \mathrm{g} / \mathrm{ml}$ aprotinin, and $1 \mathrm{mM}$ phenylmethylsulfonyl fluoride). Detergent insoluble materials were pelleted by centrifugation $\left(12,000 \times g, 15 \mathrm{~min}\right.$, at $\left.4^{\circ} \mathrm{C}\right)$, and the soluble supernatant fraction was removed and stored at either $-80^{\circ} \mathrm{C}$ or used immediately. Protein concentrations in the lysates were determined using Bradford protein assay reagent.

\section{Electrophoresis and immunoblot analysis}

Protein samples were prepared for electrophoresis then separated using a $10 \%$ SDS-polyacrylamide gel and the buffer system described previously (Bae et al., 2003). Following the electrophoresis, the proteins were blotted onto nitrocellulose membrane, which was blocked by incubating with TBST (Trisbuffered saline, $0.05 \%$ Tween-20) containing 5\% non-fat dried milk. The membranes were then incubated with anti-phospho-ERK antibody, anti-phosphop38 kinase antibody or anti-ERK antibody and washed with TBST. Antigen-antibody complexes were visualized after incubating the membrane with $1: 5,000$ diluted goat anti-rabbit IgG or goat antimouse IgG antibody coupled to horseradish peroxidase using the enhanced chemiluminescence detection system.

\section{Chemotaxis assay}

Chemotaxis assays were performed using multiwell chambers (Neuroprobe Inc., Gaithersburg, MD) as described previously (Bae et al., 2003). Briefly, polycarbonate filters ( $8 \mu \mathrm{m}$ pore size) were precoated with $20 \mu \mathrm{g} / \mathrm{ml}$ of fibronectin in HEPES-buffered RPMI 1640 medium. A dry coated filter was placed on a 96-well chamber containing different concentrations of PhS1P. L2071 cells were suspended in 
RPMI 1640 medium at a concentration of $1 \times 10^{6}$ cells $/ \mathrm{ml}$, and $25 \mu \mathrm{l}$ of the cell suspension were placed onto the upper well of the chamber. After incubation for $4 \mathrm{~h}$ at $37^{\circ} \mathrm{C}$, non-migrating cells were removed by scraping, and cells that migrated across the filter were dehydrated, fixed, and stained with hematoxylin (Sigma, St. Louis, MO). The stained cells in three randomly chosen high power field $(400 \times)$ were then counted for each well.

\section{Reverse transcription-PCR analysis}

mRNA was isolated by using a QIAshredder and an RNeasy kit (Qiagen, Hilden, Germany). mRNA, M-MLV reverse transcriptase, and $\operatorname{pd}(N)_{6}$ primers
(Invitrogen Corporation, Carlsbad, CA) were used to obtain cDNA. The sequences of the primer used

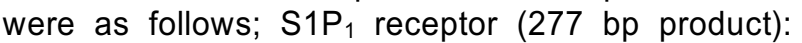
forward, 5'-ACCTTTGGCACTTTTATTGA-3'; reverse, 5'-AATACCTAGTGACAGCCGAA-3'. S1P 2 receptor (298 bp product): forward, 5'- GTTAACCAAGCCACAGAGAG-3'; reverse, 5'-GTAGAGAGGCCCTAAAAAGG-3'. S1P $\mathrm{P}_{3}$ receptor (245 bp product): forward, 5'-AAACCAGTGACACCAGAGAC-3'; reverse, 5'-GATTGGGCATCAAATGTAGT-3'. S1P 4 receptor (192 bp product); forward, 5'-ATACAGTTGGAACAGTTGGG-3'; reverse, 5'-GCAACTGTGGGTATGACTCT-3'. We ran $30 \mathrm{PCR}$ cycles at $94^{\circ} \mathrm{C}$ (denaturation, $1 \mathrm{~min}$ ), $62^{\circ} \mathrm{C}$ (annealing, $1 \mathrm{~min}$ ), and $72^{\circ} \mathrm{C}$ (extension, $1 \mathrm{~min}$ ). PCR products were electrophoresed on

\section{A}

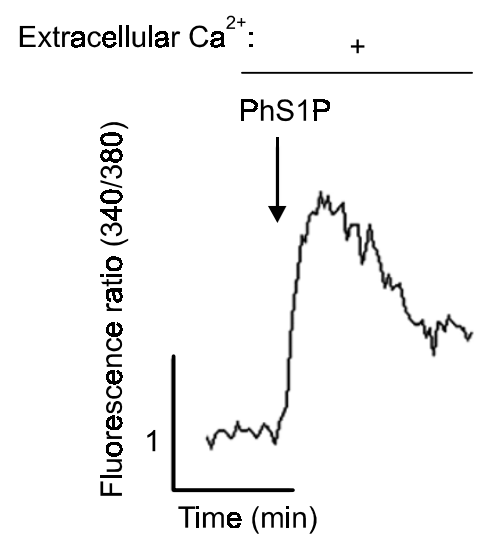

C

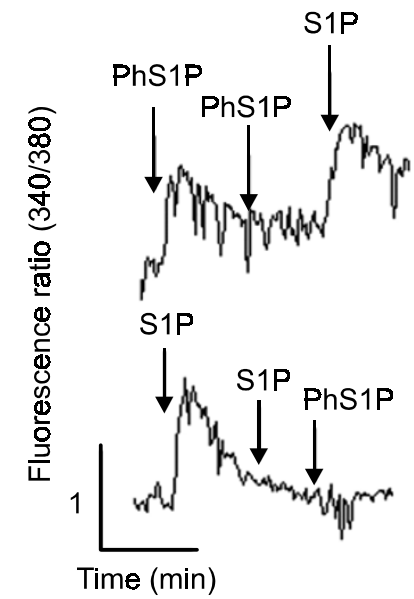

B

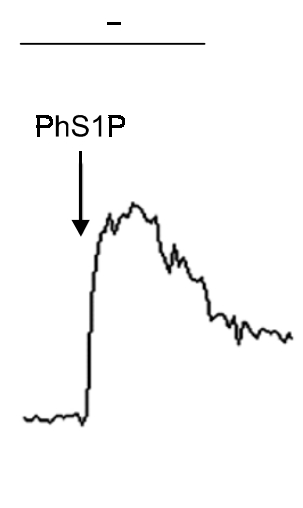

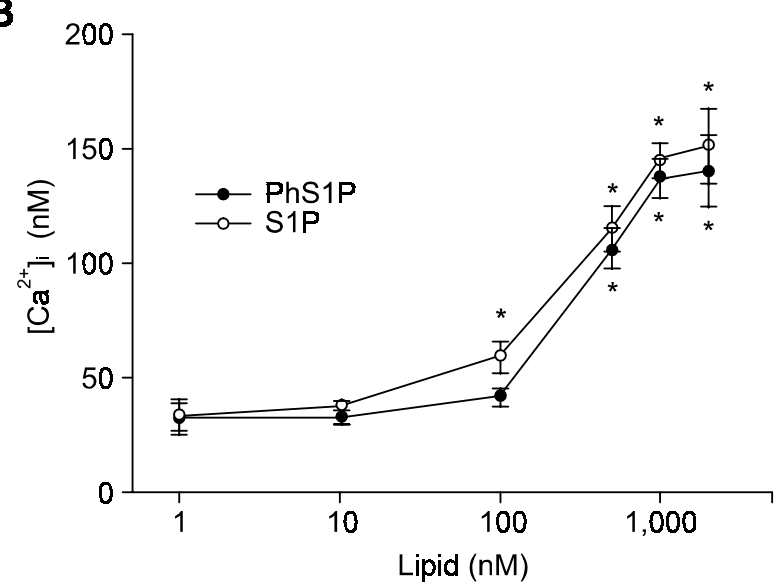

D

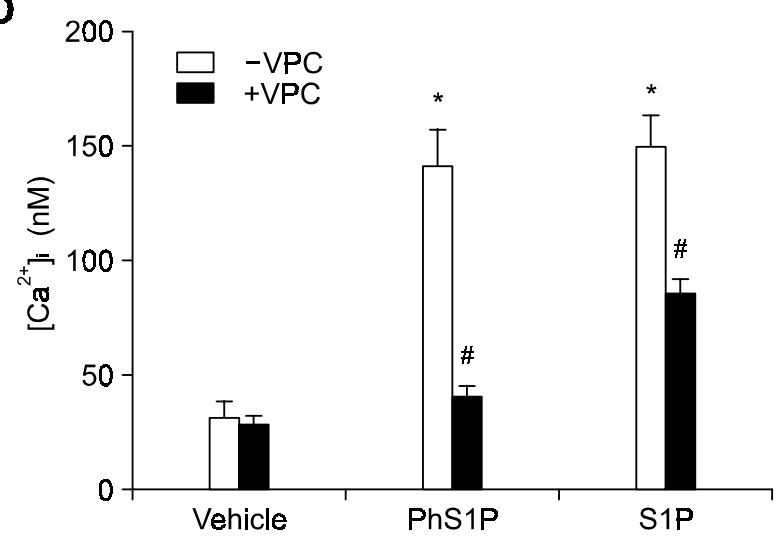

Figure 1. Effect of PhS1P on $\left[\mathrm{Ca}^{2+}\right]$ in L2071 cells. L2071 cells were stimulated with $2 \mu \mathrm{M}$ PhS1P in the absence or presence of extracellular calcium, and peak $\left[\mathrm{Ca}^{2+}\right]_{i}$ levels were determined fluorometrically using fura-2/AM (A). L2071 cells were stimulated with various concentrations of $\mathrm{PhS1P}$, and again peak [ $\left.\mathrm{Ca}^{2+}\right]_{\mathrm{l}}$ levels were recorded. L2071 cells were challenged with $2 \mu \mathrm{M} \mathrm{PhS1P}$ or $2 \mu \mathrm{M} \mathrm{S1P}$ at the time indicated by the arrow (C). L2071 cells were pretreated with $10 \mu \mathrm{M}$ of VPC 23019 or DMSO for 3 min prior to $2 \mu \mathrm{M}$ of PhS1P, $2 \mu \mathrm{M}$ of S1P, or vehicle (ethanol), and [Ca ${ }^{2+}$ ] was determined $(D)$. Results are presented as mean \pm SEM of three independent experiments performed in duplicate $(B, D)$. * indicates results significantly different from the control (-PhS1P or $-\mathrm{S} 1 \mathrm{P})$ at the $P<0.05$ level. " indicates results significantly different from the control (-VPC) at the $P$ $<0.05$ level. 
a $2 \%$ agarose gel and visualized by ethidium bromide staining.

\section{Transient transfection of $\mathrm{S}_{1} \mathrm{P}_{4}$}

Human $\mathrm{S}_{1} \mathrm{P}_{4}$ cDNA was kindly provided from D. S. Im (Pusan National University, Korea). Transfections were performed using LipofectAMINE reagents (Invitrogen Corporation) according to the manufacturer's instructions. HEK293 cells were plated in six-well plates at a density of $5 \times 10^{5}$ cells/well and grown overnight. Cells were transfected with $2 \mu \mathrm{g}$ of each plasmid construct for $6 \mathrm{~h}$ by the Lipofectamine method. After transfection, HEK293 cells were cultured in 10\% FBS containing RPMI 1640 medium for $48 \mathrm{~h}$.

\section{Statistics}

The results are expressed as mean \pm SEM of the number of determinations indicated. Statistical significance of differences was determined by ANOVA. Significance was accepted when $P<0.05$.

\section{Results}

\section{PhS1P stimulates calcium mobilization in L2071 cells}

Activation of some GPCRs by lysolipids, such as, $\mathrm{S}_{1 P_{2}}$ or $\mathrm{LPA}_{3}$ leads to PLC activation and the subsequent production of inositol-1,4,5-trisphosphate $\left(\mathrm{IP}_{3}\right)$ and $\left[\mathrm{Ca}^{2+}\right]_{\mathrm{i}}$ increase (An et al., 1998; Kon et al., 1999). To examine whether L2071 cells express such GPCR(s) for PhS1P, we examined the effect of PhS1P on $\left[\mathrm{Ca}^{2+}\right]_{i}$ in L2071 cells. As shown in Figure 1A, the stimulation of L2071 cells with 1 $\mu \mathrm{M}$ PhS1P caused a $\left[\mathrm{Ca}^{2+}\right]_{i}$ increase in the presence or absence of extracellular calcium. The concentration-dependency of $\mathrm{PhS} 1 \mathrm{P}$-induced $\left[\mathrm{Ca}^{2+}\right]_{i}$ increase was also investigated, and an increase in $\left[\mathrm{Ca}^{2+}\right]_{i}$ was apparent at a PhS1P concentration of $500 \mathrm{nM}$ and maximal $\left[\mathrm{Ca}^{2+}\right]_{\mathrm{i}}$ activity was observed at a concentration of 1-2 $\mu \mathrm{M}$ (Figure 1B). We also measured the effect of various concentrations of S1P, which has a similar chemical structure with $\mathrm{PhS} 1 \mathrm{P}$, on $\left[\mathrm{Ca}^{2+}\right]_{i}$ increase in these cells. Moreover, S1P also induced $\left[\mathrm{Ca}^{2+}\right]_{i}$ increase, showing similar concentration-dependency with that of PhS1P (Figure 1B).

S1P is a well-known lysophospholipid that stimulates $\left[\mathrm{Ca}^{2+}\right]_{\mathrm{i}}$ rise in fibroblasts (Mattie et al., 1994). Thus, we suspected a possibility that PhS1P utilizes GPCRs for S1P to elicit $\mathrm{Ca}^{2+}$ response, and applied desensitization experiments. As shown in Figure 1C, stimulation of L2071 cells with PhS1P desensitized cells, resulting in no response to the second PhS1P stimulation, meaning homologous desensitization.
However, PhS1P-desensitized L2017 cells responded to S1P (Figure 1C). The homologous desensitization was also observed with S1P (Figure 1C). In the reverse cases, S1P-desensitized L2071 cells were not responding to PhS1P, meaning heterologous desensitization (Figure 1C). Therefore, these results suggest that PhS1P may share the same receptor(s) with those of S1P.

In order to determine whether PhS1P induces calcium signaling in L2017 cells via S1P receptors, we utilized the S1P receptor-selective antagonist, VPC 23019 which is an antagonist of S1P 1 and S1P $_{3}$ (Davis et al., 2005). As shown in Figure 1D, preincubation of L2071 cells with $10 \mu \mathrm{M}$ of VPC 23019 partially inhibited S1P-induced calcium increase. However, PhS1P-induced calcium increase was
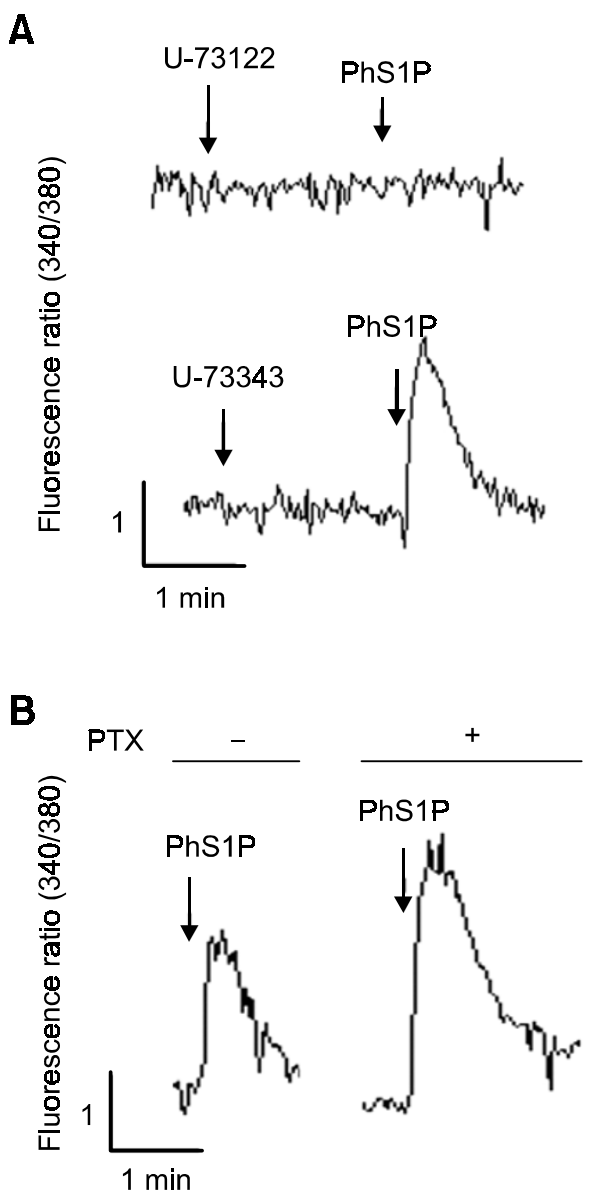

Figure 2. PhS1P-induced $\mathrm{Ca}^{2+}$ signaling is U-73122-sensitive but PTX-insensitive in L2071 cells. L2071 cells were pretreated with $5 \mu \mathrm{M}$ of U73122 or $5 \mu \mathrm{M}$ of U73343 prior to $2 \mu \mathrm{M}$ of PhS1P, and [Ca ${ }^{2+}$ ] levels were determined (A). L2071 cells were pretreated in the absence or presence of $100 \mathrm{ng} / \mathrm{ml}$ of PTX for $24 \mathrm{~h}$. Cells were then loaded with fura-2/AM and peak $\left[\mathrm{Ca}^{2+}\right]_{i}$ levels were determined fluorometrically after stimulation with $2 \mu \mathrm{M}$ of PhS1P. Data are representative of four independent experiments $(A, B)$. 
completely inhibited by preincubating L2071 cells with $10 \mu \mathrm{M}$ of VPC 23019 (Figure 1D).

\section{PhS1P-stimulated calcium mobilization is U-73122-sensitive but PTX-insensitive}

PLC-dependent $\mathrm{IP}_{3}$-mediated response is one of the most well known mechanisms of $\left[\mathrm{Ca}^{2+}\right]_{i}$ increase in the absence of extracellular calcium (Noh et al., 1995). To determine the role of PLC on PhS1Pinduced $\left[\mathrm{Ca}^{2+}\right]_{i}$ increase, we pretreated L2071 cells with a specific PLC inhibitor, U-73122, or with its inactive analogue, $U-73343$. Figure $2 \mathrm{~A}$ shows that U-73122, but not U-73343, completely inhibited $\mathrm{PhS} 1 \mathrm{P}$-induced $\left[\mathrm{Ca}^{2+}\right]_{\mathrm{i}}$ increases, which indicates that PhS1P induces $\left[\mathrm{Ca}^{2+}\right]_{i}$ increases via PLC activation in L2071 cells.

In addition, we investigated the role of PTX-sensitive G-proteins on PhS1P-induced $\left[\mathrm{Ca}^{2+}\right]_{i}$ increase.
Cultured L2071 cells were preincubated with 100 $\mathrm{ng} / \mathrm{ml}$ PTX prior to being stimulated with $1 \mu \mathrm{M}$ PhS1P. It was found that pretreatment with PTX did not block $\left[\mathrm{Ca}^{2+}\right]_{i}$ increase by PhS1P (Figure 2B), demonstrating that PhS1P induces $\left[\mathrm{Ca}^{2+}\right]_{i}$ in a PTXinsensitive manner.

\section{PhS1P stimulates ERK and p38 kinase in L2071 cells in a PTX-sensitive manner}

MAPK has been reported to mediate extracellular signals to the nucleus in various cell types (Johnson and Lapadat, 2002). In this study, we examined whether PhS1P stimulates MAPKs by Western blotting using anti-phospho-specific antibodies against each enzyme. When L2071 cells were stimulated with $1 \mu \mathrm{M}$ PhS1P for several lengths of time, ERK phosphorylation levels were transiently increased, and peaked within 2-10 $\mathrm{min}$ of stimulation, and
A

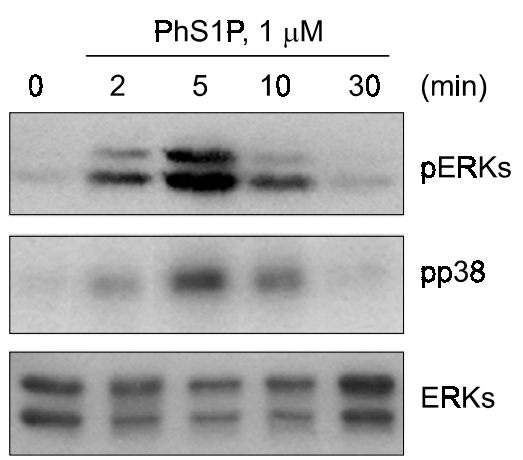

C
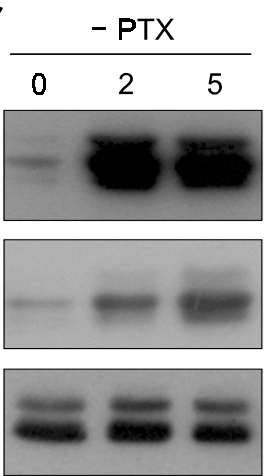

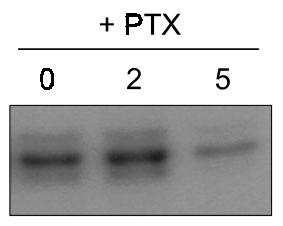

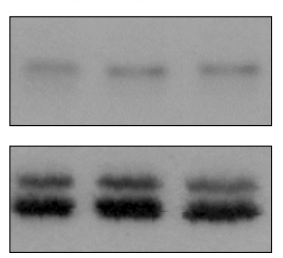

B

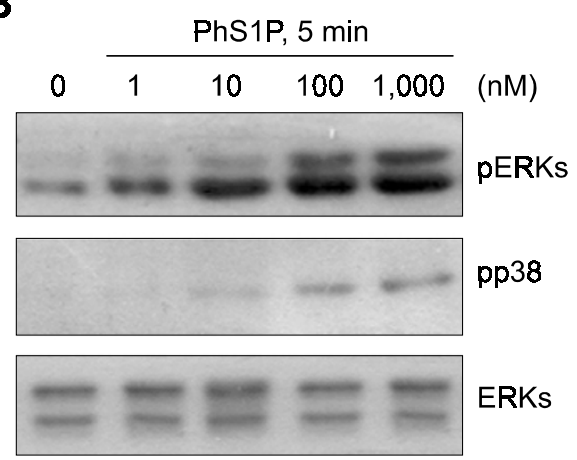

D
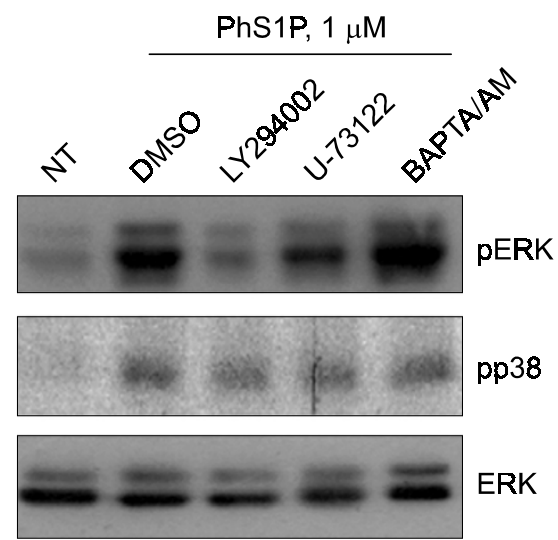

Figure 3. PhS1P stimulates MAPK phosphorylation in a PTX-sensitive manner in L2071 cells. L2071 cells were stimulated with $2 \mu \mathrm{M}$ of PhS1P for different times (A). Cells were then stimulated with various concentrations of PhS1P for $5 \mathrm{~min}$ (B). L2071 cells pretreated with/without $100 \mathrm{ng} / \mathrm{ml}$ PTX for $24 \mathrm{~h}$ were stimulated with $2 \mu \mathrm{M}$ PhS1P for 0, 2, or $5 \mathrm{~min}(\mathrm{C})$. Cells were pretreated with LY294002 $(50 \mu \mathrm{M})$, U-73122 $(5 \mu \mathrm{M})$, or BAPTA/AM $(10 \mu \mathrm{M})$ for $15 \mathrm{~min}$ prior to adding $2 \mu \mathrm{M}$ PhS1P for $5 \mathrm{~min}(\mathrm{D})$. Protein samples $(30 \mu \mathrm{g})$ were subjected to $10 \%$ SDS-PAGE, and phosphorylated ERK and p38 kinase levels were determined by immunoblotting using anti-phospho-ERK antibody or anti-phospho-p38 kinase antibody. The results shown are representative of at least three independent experiments (A-D). 
returned to baseline $30 \mathrm{~min}$ after stimulation (Figure 3A). Another important MAPK, p38 kinase was also transiently activated by PhS1P stimulation with kinetics that resembled those of ERK activation (Figure $3 \mathrm{~A})$. We also examined the concentration-dependencies of PhS1P-induced ERK and p38 kinase activations. When L2071 cells were stimulated with various concentrations of PhS1P, ERK and p38 kinase were concentration- dependently activated (Figure 3B). In terms of ERK activation, PhS1P caused significant activation at $10 \mathrm{nM}$ and maximal activation at 0.1-1 $\mu \mathrm{M}$ (Figure 3B). p38 kinase activation was also induced by PhS1P at ca. $10 \mathrm{nM}$ and maximally induced by PhS1P at $1 \mu \mathrm{M}$ (Figure 3B).

We also examined the effect of PTX, a specific inhibitor of $G_{i}$ type $G$ proteins, on PhS1P-induced MAPK phosphorylation. When L2071 cells were preincubated with $100 \mathrm{ng} / \mathrm{ml}$ PTX prior to being stimulated with $1 \mu \mathrm{M}$ PhS1P, PhS1P-induced ERK and p38 kinase phosphorylations were almost completely inhibited (Figure 3C). These results indicate that PhS1P stimulates the activations of ERK and p38 kinase via PTX-sensitive G-proteins. In addition, we examined the signaling pathway of PhS1P-induced MAPK phosphorylation by stimulating L2071 cells with PhS1P in the presence of several signaling molecule inhibitors. LY294002 and U-73122 are selective inhibitors of phosphatidylinositol-3-kinase (PI3K) and PLC, respectively (Smith et al., 1990; Vlahos et al., 1994), and BAPTA/ $\mathrm{AM}$ is a $\mathrm{Ca}^{2+}$ chelator (Tsien, 1980). As shown in Figure 3D, LY294002 completely inhibited PhS1Pinduced ERK phosphorylation, but BAPTA/AM did not (Figure 3D). U-73122 also partially inhibited PhS1P-induced ERK phosphorylation (Figure 3D). These results indicate that PhS1P stimulates ERK phosphorylation via a PI3K- and PLC-mediated pathway. In addition, PhS1P-induced p38 kinase phosphorylation was also inhibited by LY294002 or U73122 but not by BAPTA/AM (Figure 3D), suggesting that PhS1P-induced p38 kinase activation is PI3Kand PLC-dependent.

\section{PhS1P induces mouse fibroblast chemotaxis via PTX-sensitive G-proteins, p38 kinase, and PI3K-dependent signaling}

We examined the effect of PhS1P on the migration of mouse fibroblasts. Since intracellular signaling via several chemoattractant receptors results in the activation of several integrins that are involved in leukocyte adhesion and migration (Wang et al., 2002), we investigated the effect of PhS1P on fibroblast migration on specific extracellular matrices. PhS1P was found to induce the chemotactic
A

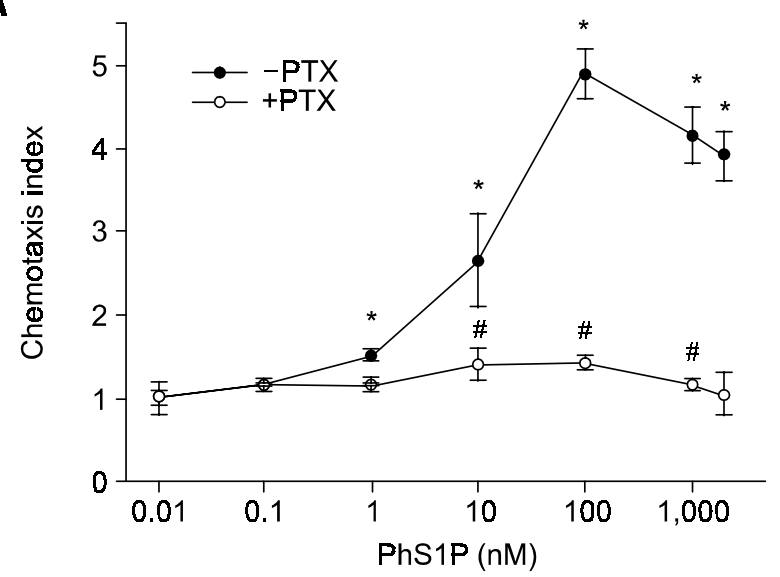

B

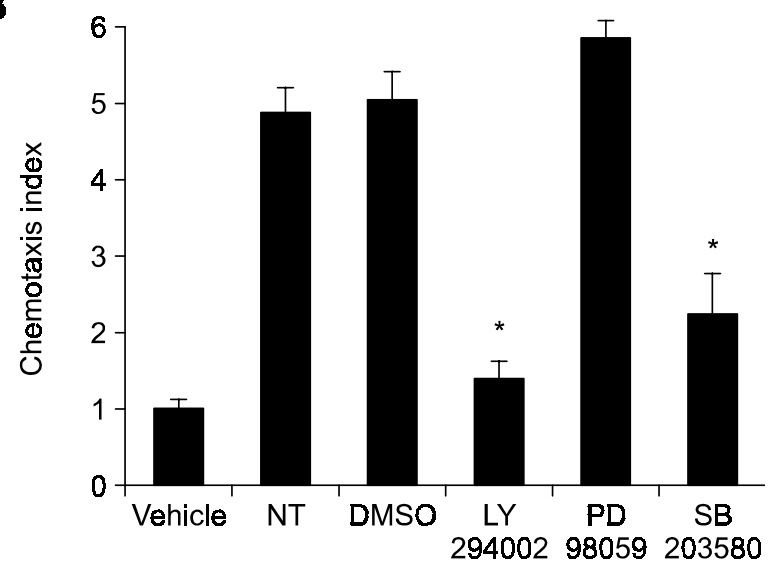

PhS1P, $100 \mathrm{nM}$

Figure 4. PhS1P induced L2071 chemotaxis via PTX-sensitive G-protein and PI3K and p38 kinase-mediated signaling. Chemotaxis assays were performed using a modified Boyden chamber assay, as described in Materials and Methods. L2071 cells, which had been pretreated with/without $100 \mathrm{ng} / \mathrm{ml}$ PTX for $24 \mathrm{~h}$, were subjected to chemotaxis assays after being treated with different concentrations of PhS1P $(0.01$, $0.1,1,10,100,1,000$, and 2,000 nM) (A). Untreated L2071 cells were pretreated with vehicle (DMSO), PD98059 (50 $\mu \mathrm{M})$, SB203580 (20 $\mu \mathrm{M})$, or LY294002 $(50 \mu \mathrm{M})$ for $15 \mathrm{~min}$, and then subjected to chemotaxis assays with $100 \mathrm{nM}$ PhS1P for $4 \mathrm{~h}(\mathrm{~B})$. The numbers of cells that migrated were counted in three high power fields $(400 \times)$. Vehicle is ethanol which was used to dissolve PhS1P. NT means not treated (neither DMSO nor other inhibitors were treated). Data are presented as the mean \pm SEM of three independent experiments performed in duplicate $(A, B)$. * indicates results significantly different from the control (-PhS1P in A, DMSO+PhS1P in B) at the $P<0.05$ level. " indicates results significantly different from the control (-PTX) at the $P<$ 0.05 level.

migration of mouse fibroblasts on fibronectin but not on fibrinogen or BSA (data not shown). Figure 4A shows the concentration-responsive curve of PhS1Pinduced mouse fibroblast migration, which showing 
maximal activity at $100 \mathrm{nM}$. These findings imply that PhS1P induces the chemotaxis of mouse fibroblasts. Moreover, since PhS1P-induced MAPK phosphorylations were inhibited by PTX in L2071 cells, we examined the effects of PTX on PhS1P-induced mouse fibroblast chemotaxis. When L2071 cells were pretreated with $100 \mathrm{ng} / \mathrm{ml}$ PTX prior to chemotaxis assays, the number of cells migrating toward PhS1P was reduced by around 90\% versus cells not treated with PTX (Figure 4A), thus strongly suggesting the involvement of PTX-sensitive $G$ protein(s) in L2071 chemotaxis.

Several reports show that many chemoattractants stimulate PI3K-mediated Akt activity and that a PI3K pathway is involved in the chemotaxis of leukocytes stimulated by these chemoattractants (Hirsch et al., 2000; Wang et al., 2002). Since we observed that the stimulation of cells with PhS1P led to a rapid increase in the phosphorylation of Akt (data not shown), we examined whether the PI3K pathway is required for PhS1P-induced L2071 cell chemotaxis, and we found that pretreatment of cells with $50 \mu \mathrm{M}$ LY294002 (a well-known PI3K inhibitor) for $15 \mathrm{~min}$ at $37^{\circ} \mathrm{C}$ prior to stimulation with $\mathrm{PhS} 1 \mathrm{P}$ did indeed affect cellular chemotaxis (Figure 4B). These results indicate that PhS1P activates the PI3K pathway and that this signaling is required for the PhS1P-induced chemotaxis of L2071 mouse fibroblast cells.

We also examined the roles of ERK and p38 kinase on PhS1P-induced L2071 chemotaxis. PD98059 and SB203580 are selective inhibitors of ERK and p38 kinase, respectively (Kim et al., 2006; Lee et al., 2006). When L2071 cells were preincubated with PD98059 or SB203580 prior to chemotaxis assays, PhS1P-induced L2071 chemotaxis was significantly blunted by SB203580, but PhS1P-induced chemotaxis was not inhibited by PD98059 (Figure 4B), which implies that p38 kinase-mediated signaling is involved in PhS1P-induced L2071 chemotaxis.

\section{PhS1P stimulates L2071 chemotaxis independently of $\mathrm{S}_{1 \mathrm{P}}, \mathrm{S}_{1} \mathrm{P}_{3}$ and $\mathrm{S}_{1 \mathrm{P}}$}

To determine whether L2071 cells express receptors for PhS1P, we analyzed the mRNA expressions of $\mathrm{S}_{1} \mathrm{P}_{1-4}$ by semi-quantitative RT-PCR. As shown in Fig. 5A, L2071 cells expressed several forms of S1P receptors, namely, $\mathrm{S}_{1} \mathrm{P}_{1}, \mathrm{~S}_{1} \mathrm{P}_{2}, \mathrm{~S}_{1} \mathrm{P}_{3}$, and $\mathrm{S}_{1} \mathrm{P}_{4}$, and the expression levels of $\mathrm{S}_{1} \mathrm{P}_{2}$ and $\mathrm{S}_{1} \mathrm{P}_{3}$ were higher than those of $\mathrm{S}_{1} \mathrm{P}_{1}$ and $\mathrm{S}_{1} \mathrm{P}_{4}$.

In order to determine whether PhS1P induces L2071 chemotaxis via S1P receptors, we utilized VPC 23019 which is an antagonist of $\mathrm{S}_{1} \mathrm{P}_{1}$ and $\mathrm{S}_{1} \mathrm{P}_{3}$ (Davis et al., 2005). As shown in Figure 5B, S1P. induced L2071 chemotaxis was completely inhibited by pretreating L2071 cells with $10 \mu \mathrm{M}$ VPC 23019.
A

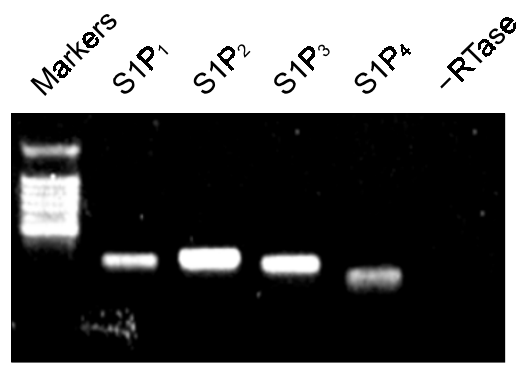

B

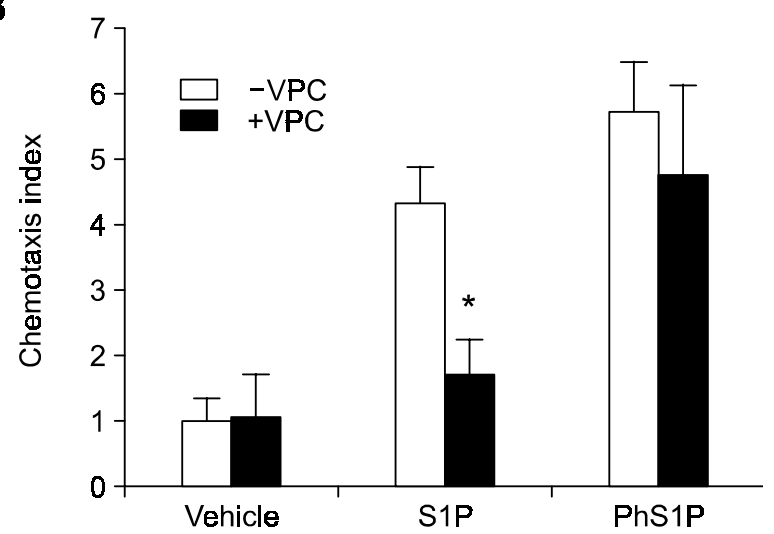

C

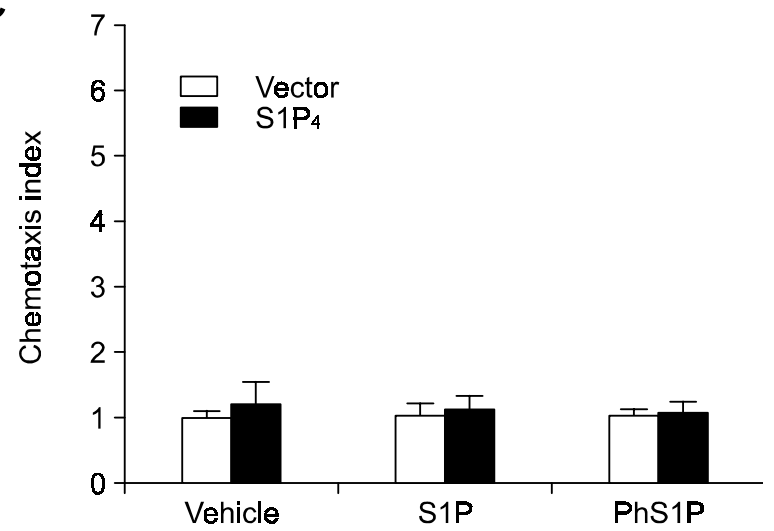

Figure 5. PhS1P stimulated L2071 chemotaxis independently of $\mathrm{S}_{1} \mathrm{P}_{1}, \mathrm{~S}_{1} \mathrm{P}_{3}$, and $\mathrm{S}_{\mathrm{P}}$. RT-PCR analysis was performed on mRNA isolated from cultured L2071 mouse fibroblasts. The data presented are representative of three independent experiments. RTase indicates Maloney murine leukemia virus reverse transcriptase (A). L2071 cells were treated with vehicle (DMSO) or VPC 23019 (10 $\mu \mathrm{M})$ for $15 \mathrm{~min}$, and then subjected to chemotaxis assays in the presence of $1 \mu \mathrm{M} \mathrm{S1P}$ or $100 \mathrm{nM}$ PhS1P for $4 \mathrm{~h}(\mathrm{~B})$. HEK293 cells were transfected with vector or $\mathrm{S}^{\mathrm{P}} \mathrm{P}_{4}$ for $48 \mathrm{~h}$, and then subjected to chemotaxis assays in the presence of $1 \mu \mathrm{M} \mathrm{S1P}$ or $100 \mathrm{nM}$ PhS1P for $4 \mathrm{~h}(\mathrm{C})$. Migrated cell numbers were determined by counting in three high power fields $(400 \times)$. Data are presented as the mean \pm SEM of three independent experiments performed in duplicate $(B, C)$. * Statistically significant from the control (-VPC) at the $P<0.05$ level. 
However, PhS1P-induced L2071 chemotaxis was unaffected by pretreating with this material (Figure $5 \mathrm{~B})$. These results suggest that $\mathrm{PhS1P}$ stimulates L2071 chemotaxis independently of S1P 1 and $\mathrm{S}_{1} \mathrm{P}_{3}$.

We further examined the effect of S1P or PhS1P on cell migration in vector- or $\mathrm{S}_{1} \mathrm{P}_{4}$-transfected HEK293 cells. Cell migration by PhS1P was not significantly increased in $\mathrm{S}_{1} \mathrm{P}_{4}$-transfected HEK293 cells against vector-transfected HEK293 cells (Figure $5 \mathrm{C}$ ).

\section{Discussion}

Fibroblast migration is required for the remodeling of the provisional extracellular matrix, as fibroblasts provide a fibrous attachment for growing tissue and wound healing (Wilberding et al., 2001; Hotary et al., 2002), and thus, the modulation of chemotactic migration is an important issue in fibroblast biology. Several groups have reported that various extracellular stimuli are involved in the regulation of fibroblast chemotactic migration (Kundra et al., 1994; Hama et al., 2004). However, the role of PhS1P in fibroblast chemotaxis has not been studied. In the present study, we found that PhS1P stimulates the chemotactic migration of mouse fibroblasts L2071 cells, which suggests that $\mathrm{PhS1P}$ has a potential role in tissue remodeling, wound healing, and various functional issues related to fibroblast migration.

Previous reports have suggested that $\mathrm{S}_{1} \mathrm{P}_{1}$ and $\mathrm{S}_{1 \mathrm{P}}$, types of $\mathrm{S} 1 \mathrm{P}$ receptors, are specific cell surface receptors of PhS1P (Candelore et al., 2002; Inagaki et al., 2005). Here, we also found that PhS1P increased $\left[\mathrm{Ca}^{2+}\right]_{\mathrm{i}}$ in $\mathrm{L} 2071$ cells, and that this $\mathrm{PhS} 1 \mathrm{P}$-induced $\mathrm{Ca}^{2+}$ response was desensitized by pretreating S1P (Figure $1 \mathrm{C}$ ), which suggests that PhS1P acts on a S1P receptor in mouse fibroblasts. To further support our notion that PhS1P stimulates L2071 cells via its specific receptor, we examined the effect of the S1P receptor antagonist (VPC 23019) on the PhS1P-induced chemotactic migration of L2071 mouse fibroblast cells. Since PhS1P-induced migration was not inhibited by VPC 23019, an antagonist of $\mathrm{S}_{1} \mathrm{P}_{1}$ and $\mathrm{S}_{1} \mathrm{P}_{3}$ (Davis et al., 2005), and $\mathrm{PhS} 1 \mathrm{P}$-induced migration was not increased in $\mathrm{S} 1 \mathrm{P}_{4}$-transfected HEK293 cells (Figure 5), we suggest that PhS1P stimulates L2071 mouse fibroblasts chemotaxis independently of known its receptors, $\mathrm{S}_{1 \mathrm{P}}$ and $\mathrm{S}_{1} \mathrm{P}_{4}$. Previous reports have demonstrated that S1P receptor family members have various roles on chemotactic migration (Matloubian et al., 2004; Goparaju et al., 2005; Wang et al., 2005). Matloubian et al. (2004) found that S1P is essential for lymphocyte recruitment, whereas Go- paraju et al. (2005) reported that $\mathrm{S}_{1} \mathrm{P}_{2}$ regulates cell migration in an inhibitory manner. Recently Goetzl and colleagues demonstrated that the S1P- S1P 4 $\mathrm{T}$-cell axis does not induce cellular migration, but rather suppresses $\mathrm{T}$ cell proliferation and the generation of several cytokines, e.g., IL-2, IL-4, and IFN- $\gamma$ (Wang et al., 2005). Because previous reports on the receptors for $\mathrm{PhS1P}$ are very limited to $\mathrm{S}_{1} \mathrm{P}_{1}$ and $\mathrm{S}_{1} \mathrm{P}_{4}$, it should be considered the possibility that PhS1P can bind to other receptors besides the known S1P receptors, resulting in chemotactic migration. The findings of the present study suggest that other receptor except $\mathrm{S}_{1} \mathrm{P}_{1}$ and $\mathrm{S}_{1} \mathrm{P}_{4}$ may be involved in PhS1P-induced L2071 mouse fibroblast chemotactic migration.

In this study, we also investigated the effect of PTX, which specifically inactivates $\mathrm{G}_{\mathrm{i} / \mathrm{o}-\text { mediated sig- }}$ naling pathways, on PhS1P-induced signaling. When L2071 cells were pretreated with $100 \mathrm{ng} / \mathrm{ml}$ of PTX for $24 \mathrm{~h}$ prior to PhS1P stimulation, the PhS1P-induced $\left[\mathrm{Ca}^{2+}\right]_{i}$ increase was not inhibited (Figure 2B). However, the activations of ERK and p38 kinase and the chemotactic migration induced by PhS1P were completely inhibited by pretreating $\mathrm{PTX}$, as shown in Figures 3 and 4 . These results also imply that PhS1P utilizes PTX-sensitive GPCR. Our investigation of signals triggering $\mathrm{PhS} 1 \mathrm{P}$-induced chemotaxis in L2071 cells, based on the use of the specific inhibitors PD98059, SB203580, and LY294002 and Western blotting, identified that p38 kinase and PI3K have critical roles in this process. Taken together, it is viewed that PhS1P stimulates at least two different G-protein-coupled signals; one which involves PTX-insensitive G-protein-mediated PLC activation and a $\left[\mathrm{Ca}^{2+}\right]_{i}$ increase, and which involves PTX-sensitive G-protein-mediated chemotactic migration via p38 kinase and PI3K. Moreover, as calcium signaling regulates various kinds of cellular physiologies and PhS1P dramatically stimulates a PLC-mediated $\left[\mathrm{Ca}^{2+}\right]_{i}$ increase, it would be interesting to examine the functional roles of PhS1P in mouse fibroblasts in terms of calcium signalingdependent processes, as it is felt that this type of work would probably unearth additional important lipid-mediating roles for PhS1P.

In conclusion, in this study, we found that PhS1P induces the chemotactic migration of L2071 mouse fibroblasts by modulating the activities of several intracellular signaling molecules, like p38 kinase and $\mathrm{PI} 3 \mathrm{~K}$, and transmembrane signaling molecules, like PTX-sensitive trimeric $G$ proteins and PLC. Since this study represents the only report issued to date on the role of PhS1P on mouse fibroblast chemotaxis, further studies on the pathologic and physiologic roles of PhS1P, and on the roles of PhS1P specific cell surface receptor(s) in L2071 cells are 
required.

\section{Acknowledgement}

This work was supported by the Dong-A University Research Fund in 2006.

\section{References}

An S, Bleu T, Huang W, Hallmark OG, Coughlin SR, Goetzl EJ. Identification of cDNAs encoding two $G$ protein-coupled receptors for lysosphingolipids. FEBS Lett 1997;417:279-82

An S, Bleu T, Zheng Y, Goetzl EJ. Recombinant human G protein-coupled lysophosphatidic acid receptors mediate intracellular calcium mobilization. Mol Pharmacol 1998;54: 881-8

An S, Zheng Y, Bleu T. Sphingosine 1-phosphate-induced cell proliferation, survival, and related signaling events mediated by $\mathrm{G}$ protein-coupled receptors Edg3 and Edg5. J Biol Chem 2000;275:288-96

Bae YS, Yi HJ, Lee HY, Jo EJ, Kim JI, Lee TG, Ye RD, Kwak JY, Ryu SH. Differential activation of formyl peptide receptor-like 1 by peptide ligands. J Immunol 2003;171:680713

Candelore MR, Wright MJ, Tota LM, Milligan J, Shei GJ, Bergstrom JD, Mandala SM. Phytosphingosine 1-phosphate: a high affinity ligand for the S1P(4)/Edg-6 receptor. Biochem Biophys Res Commun 2002;297:600-6

Cummings RJ, Parinandi NL, Zaiman A, Wang L, Usatyuk PV, Garcia JG, Natarajan V. Phospholipase D activation by sphingosine 1-phosphate regulates interleukin-8 secretion in human bronchial epithelial cells. J Biol Chem 2002;277: 30227-35

Davis MD, Clemens JJ, Macdonald TL, Lynch KR. Sphingosine 1-phosphate analogs as receptor antagonists, J Biol Chem 2005;280:9833-41

Dickson RC. Sphingolipid functions in Saccharomyces cerevisiae: comparison to mammals. Annu Rev Biochem 1998;67:27-48

English D, Kovala AT, Welch Z, Harvey KA, Siddiqui RA, Brindley DN, Garcia JG. Induction of endothelial cell chemotaxis by sphingosine 1-phosphate and stabilization of endothelial monolayer barrier function by lysophosphatidic acid, potential mediators of hematopoietic angiogenesis. $J$ Hematother Stem Cell Res 1999;8:627-34

Fishman DA, Liu Y, Ellerbroek SM, Stack MS. Lysophosphatidic acid promotes matrix metalloproteinase (MMP) activation and MMP-dependent invasion in ovarian cancer cells. Cancer Res 2001;61:3194-9

Goparaju SK, Jolly PS, Watterson KR, Bektas M, Alvarez S, Sarkar S, Mel L, Ishii I, Chun J, Milstien S, Spiegel S. The S1P2 receptor negatively regulates platelet-derived growth factor-induced motility and proliferation. Mol Cell Biol 2005; 25:4237-49

Grynkiewicz G, Poenie M, Tsien RY. A new generation of $\mathrm{Ca}^{2+}$ indicators with greatly improved fluorescence properties. J Biol Chem 1985;260:3440-50

Hama K, Aoki J, Fukaya M, Kishi Y, Sakai T, Suzuki R, Ohta $\mathrm{H}$, Yamori T, Watanabe M, Chun J, Arai H. Lysophosphatidic acid and autotaxin stimulate cell motility of neoplastic and non-neoplastic cells through LPA1. J Biol Chem 2004;279: 17634-9

Hirsch E, Katanaev VL, Garlanda C, Azzolino O, Pirola L, Silengo L, Sozzani S, Mantovani A, Altruda F, Wymann MP. Central role for $G$ protein-coupled phosphoinositide 3-kinase gamma in inflammation. Science 2000;287:1049-53

Hotary KB, Yana I, Sabeh F, Li XY, Holmbeck K, BirkedalHansen H, Allen ED, Hiraoka N, Weiss SJ. Matrix metalloproteinases (MMPs) regulate fibrin-invasive activity via MT1-MMP-dependent and -independent processes. J Exp Med 2002;195:295-308

Idzko M, Panther E, Corinti S, Morelli A, Ferrari D, Herouy Y, Dichmann S, Mockenhaupt M, Gebicke-Haerter P, Di Virgilio F, Girolomoni G, Norgauer J. Sphingosine 1-phosphate induces chemotaxis of immature and modulates cytokinerelease in mature human dendritic cells for emergence of Th2 immune responses. FASEB J 2002;16:625-7

Inagaki Y, Pham TT, Fujiwara Y, Kohno T, Osborne DA, Igarashi Y, Tigyi G, Parrill AL. Sphingosine 1-phosphate analogue recognition and selectivity at S1P4 within the endothelial differentiation gene family of receptors. Biochem J 2005; 389:187-95

Johnson GL, Lapadat R. Mitogen-activated protein kinase pathways mediated by ERK, JNK, and p38 protein kinases. Science 2002;298:1911-2

Kim HS, Yumkham S, Kim SH, Yea K, Shin YC, Ryu SH, Suh PG. Secretin induces neurite outgrowth of PC12 through cAMP-mitogen-activated protein kinase pathway. Exp Mol Med 2006;38:85-93

Kim JI, Jo EJ, Lee HY, Kang HK, Lee YN, Kwak JY, Bae YS. Stimulation of early gene induction and cell proliferation by lysophosphatidic acid in human amnion-derived WISH cells: role of phospholipase D-mediated pathway. Biochem Pharmacol 2004;68:333-40

Kon J, Sato K, Watanabe T, Tomura H, Kuwabara A, Kimura T, Tamama K, Ishizuka T, Murata N, Kanda T, Kobayashi I, Ohta $\mathrm{H}$, Ui M, Okajima F. Comparison of intrinsic activities of the putative sphingosine 1-phosphate receptor subtypes to regulate several signaling pathways in their cDNA-transfected Chinese hamster ovary cells. J Biol Chem 1999;274:23940-7

Kundra V, Escobedo JA, Kazlauskas A, Kim HK, Rhee SG, Williams LT, Zetter BR. Regulation of chemotaxis by the platelet-derived growth factor receptor-beta. Nature 1994; 367:474-6

Lee KH, Choi EY, Kim MK, Hyun MS, Jang BI, Kim TN, Kim SW, Song SK, Kim JH, Kim JR. Regulation of hepatocyte growth factor-mediated urokinase plasminogen activator secretion by MEK/ERK activation in human stomach cancer cell lines. Exp Mol Med 2006;38:27-35

Matloubian M, Lo CG, Cinamon G, Lesneski MJ, Xu Y, Brinkmann V, Allende ML, Proia RL, Cyster JG. Lymphocyte egress from thymus and peripheral lymphoid organs is 
dependent on S1P receptor 1. Nature 2004;427:355-60

Mattie M, Brooker G, Spiegel S. Sphingosine-1-phosphate, a putative second messenger, mobilizes calcium from internal stores via an inositol trisphosphate-independent pathway. J Biol Chem 1994;269:3181-8

Noh DY, Shin SH, Rhee SG. Phosphoinositide-specific phospholipase $\mathrm{C}$ and mitogenic signaling. Biochim Biophys Acta 1995;1242:99-113

Okamoto H, Takuwa N, Gonda K, Okazaki H, Chang K, Yatomi Y, Shigematsu $H$, Takuwa Y. EDG1 is a functional sphingosine1-phosphate receptor that is linked via a $\mathrm{G}_{\mathrm{i} / \mathrm{o}}$ to multiple signaling pathways, including phospholipase $\mathrm{C}$ activation, $\mathrm{Ca}^{2+}$ mobilization, Ras-mitogen-activated protein kinase activation, and adenylate cyclase inhibition. J Biol Chem 1998;273:27104-10

Schurer NY, Plewig G, Elias PM. Stratum corneum lipid function. Dermatologica 1991;183:77-94

Smith RJ, Sam LM, Justen JM, Bundy GL, Bala GA, Bleasdale JE. Receptor-coupled signal transduction in human polymorphonuclear neutrophils: effects of a novel inhibitor of phospholipase C-dependent processes on cell responsiveness. J Pharmacol Exp Ther 1990;253:688-97

Tsien RY. New calcium indicators and buffers with high selectivity against magnesium and protons: design, synthesis, and properties of prototype structures. Biochemistry 1980;19: 2396-404

van Corven EJ, Groenink A, Jalink K, Eichholtz T, Moolenaar WH. Lysophosphatidate-induced cell proliferation: identifica- tion and dissection of signaling pathways mediated by $G$ proteins. Cell 1989;59:45-54

Vlahos CJ, Matter WF, Hui KY, Brown RF. A specific inhibitor of phosphatidylinositol 3-kinase, 2-(4-morpholinyl)-8-phenyl4H-1-benzopyran-4-one (LY294002). J Biol Chem 1994;269: $5241-8$

Wang C, Hayashi H, Harrison R, Chiu B, Chan JR, Ostergaard $\mathrm{HL}$, Inman RD, Jongstra J, Cybulsky MI, Jongstra-Bilen J. Modulation of Mac-1 (CD11b/CD18)-mediated adhesion by the leukocyte-specific protein 1 is key to its role in neutrophil polarization and chemotaxis. J Immunol 2002;169:415-23

Wang F, Van Brocklyn JR, Hobson JP, Movafagh S, Zukowska-Grojec Z, Milstien S, Spiegel S. Sphingosine 1-phosphate stimulates cell migration through a G(i)-coupled cell surface receptor. Potential involvement in angiogenesis. J Biol Chem 1999;274:35343-50

Wang W, Graeler MH, Goetzl EJ. Type 4 sphingosine 1-phosphate $\mathrm{G}$ protein-coupled receptor (S1P4) transduces S1P effects on $T$ cell proliferation and cytokine secretion without signaling migration. FASEB J 2005;19:1731-3

Wilberding JA, Ploplis VA, McLennan L, Liang Z, Cornelissen I, Feldman M, Deford ME, Rosen ED, Castellino FJ. Development of pulmonary fibrosis in fibrinogen-deficient mice. Ann N Y Acad Sci 2001;936:542-8

Yamazaki Y, Kon J, Sato K, Tomura H, Sato M, Yoneya T, Okazaki H, Okajima F, Ohta H. Edg-6 as a putative sphingosine 1-phosphate receptor coupling to $\mathrm{Ca}(2+)$ signaling pathway. Biochem Biophys Res Commun 2000;268:583-9 